\title{
The Lake Edgar Fault: an active fault in Southwestern Tasmania, Australia, with repeated displacement in the Quaternary
}

\author{
Kevin McCue $\left({ }^{1}\right)$, Russ Van Dissen $\left({ }^{2}\right)$, Gary Gibson $\left({ }^{3}\right)$, Vagn Jensen $\left({ }^{4}\right)$ and Bruce Boreham $\left({ }^{5}\right)$ \\ (') Australian Seismological Centre, Canberra, Australia \\ $\left.{ }^{2}\right)$ Institute of Geological and Nuclear Sciences, Lower Hutt, New Zealand \\ $\left(^{3}\right)$ Seismology Research Centre, Richmond, Victoria, Australia \\ (4) University of Tasmania, Hobart Tasmania, Australia \\ $\left({ }^{5}\right)$ Department of Industry, Tourism and Resources, Canberra, Australia
}

\begin{abstract}
The Lake Edgar Fault in Western Tasmania, Australia is marked by a prominent fault scarp and is a recently reactivated fault initially of Cambrian age. The scarp has a northerly trend and passes through the western abutment of the Edgar Dam, a saddle dam on Lake Pedder. The active fault segment displaces geologically young river and glacial deposits. It is $29 \pm 4 \mathrm{~km}$ long, and dips to the west. Movement on the fault has ruptured the ground surface at least twice within the Quaternary and possibly the last $c a .25000$ years; the most recent rupture has occurred since the last glaciation (within the last $c a$. 10000 years). This is the only known case of surface faulting in Australia with evidence for repeated ruptures in the Late Pleistocene. Along its central portion the two most recent surface-faulting earthquakes have resulted in about $2.5 \mathrm{~m}$ of vertical displacement each (western side up). The Lake Edgar Fault is considered capable of generating earthquakes in the order of magnitude 61/2-71/4. The Gell River Fault is another fault nearby that was apparently also active in the Late Pleistocene. It has yet to be studied in detail but the scarp appears to be more degraded and therefore older than the most recent movement on the Lake Edgar Fault.
\end{abstract}

Key words recent faults - Australia - intraplate seismicity - multiple ruptures

\section{Introduction}

Since 1968, five of Australia's largest earthquakes have ruptured the ground surface (McCue, 1990; Crone et al., 1997). These five surface ruptures comprise nearly half of all known historical surface ruptures during earthquakes in stable continental regions throughout

Mailing address: Mr. Kevin McCue, Australian Seismological Centre, PO Box 324, Jamison Centre ACT 2614, Australia; e-mail: asc@netspeed.com.au the globe (Johnston et al., 1994). The fault scarps produced by these earthquakes are quite impressive features in the landscape - extending for some tens of kilometres in length and up to several metres in height. These scarps preserve information related to the earthquake's location, size and the timing of the past event or sequence of events.

There were eight large shallow earthquakes with a magnitude of 6.0 or more in Australia between 1901 and 1967 and another eleven between 1968 and 2000. The largest, in 1906, had a magnitude of $M_{S}$ 7.2. None of the pre1968 20th century events are known to have caused surface ruptures.

More than a dozen fault scarps of Late Quaternary age have been discovered to date in 


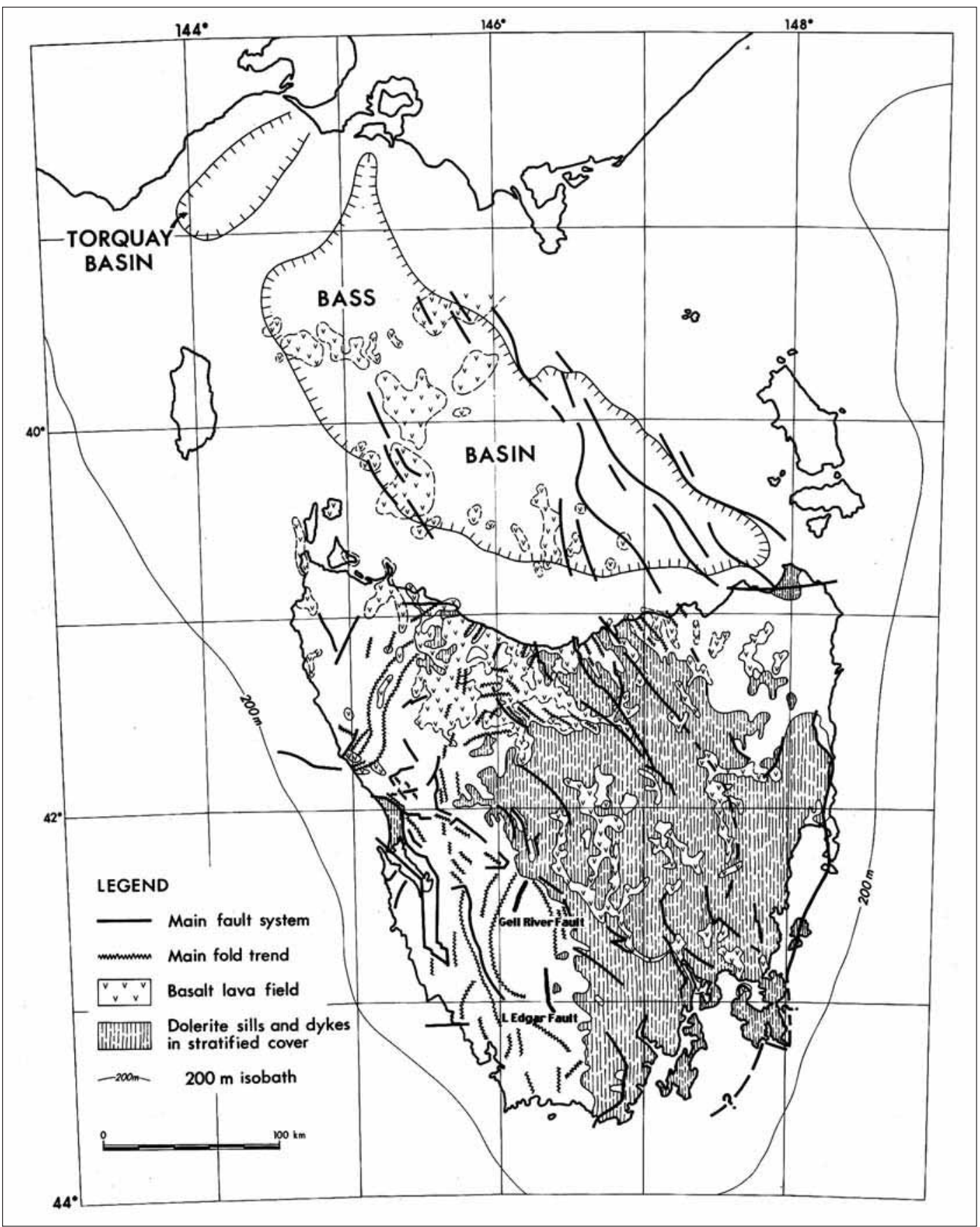

Fig. 1. Simplified geological map of Tasmania showing the location of the Lake Edgar and Gell River faults (after Burrett and Martin, 1989). 
Australia (McCue, 2001) so there is little doubt that the past 35 years are not so unusual in relation to the frequency of large earthquakes. The study of these fault scarps and related geology will provide critical information for defining Australian earthquake source zones, determining the long-term average recurrence rate of large earthquakes, and assessing earthquake hazard in Australia. Such study should also contribute to the debate on whether the source regions of the five fault scarps produced since 1968 are still capable of producing further large earthquakes.

The purpose of this paper is to present results from our two field studies of the pre-historic Lake Edgar Fault scarps of Southwestern Tasmania (fig. 1). We describe the features of the fault, and then present evidence for repeated surface-faulting earthquakes on the Lake Edgar Fault within the Quaternary (the last $c a$. $2 \mathrm{Ma}$ ). We conclude with some speculative comments regarding possible spatial and temporal relations between surface-faulting earthquakes on the Lake Edgar Fault and on a second active fault approximately $40 \mathrm{~km}$ to the north, the Gell River Fault.

This part of Southwestern Tasmania supports temperate rainforest and button grass plains, and experiences ten times the average rainfall of the semi-arid regions of southwest Western Australia and Central Australia where the five other scarp-producing events, including the 1968 Meckering and 1988 Tennant Creek earthquakes, occurred.

\section{Lake Edgar Fault}

\subsection{Fault geometry}

The Lake Edgar Fault is located about $70 \mathrm{~km}$ inland from Tasmania's western and southern coastlines in the Tasmanian Wilderness World Heritage Area and a similar distance west of Hobart the capital city (fig. 1). Being a World Heritage listed area, no trenching is allowed, access is difficult and sampling restricted.

The fault was first noted and partially mapped by Carey and Newstead (1960) who identified it as a recently reactivated fault, initially of
Cambrian age (ca. $540 \mathrm{Ma}$ ). It is within a Precambrian inlier or region called the Jubilee region within which the subsurface continuity of Precambrian rocks is thought to be likely (Turner, 1989). Precambrian rocks underlie about $20 \%$ of Tasmania. According to Turner the inliers are separated by either folded strata of latest Precambrian to Devonian age or relatively flat lying Carboniferous to Cainozoic strata.

The fault has a northerly trend and is upthrown to the west. Carey and Newstead also reproduced a copy of an aerial photograph showing two small shallow lakes formed by ponding of streams against the upthrown block (fig. 2). Note the fans emanating westward from the ranges to the east. From the photograph we infer that the lakes were once joined, the larger rem-

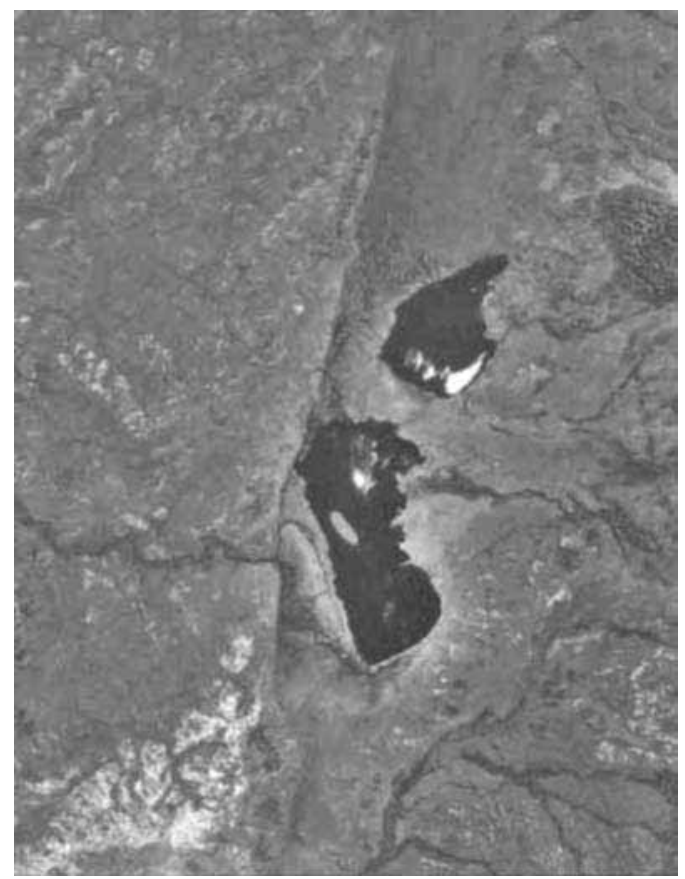

Fig. 2. Airphoto of the Lake Edgar Fault prior to the filling of Lake Pedder, north up the page. Creeks draining from mountains to the east have ponded against the $2 \mathrm{~m}$ high scarp, forming a lake which has since partially dried leaving two small lakes, the southern one is Lake Edgar. 
nant was called Lake Edgar, hence the name of the fault. Carey and Newstead commented on the youthfulness of the fault scarp based on the observation that the ponds had not yet silted up despite the high average annual rainfall of more than $2500 \mathrm{~mm} / \mathrm{yr}$. These ponds were drowned when the Gordon, Scott's Peak and Edgar Dams were built in the early 1970s creating Lake Pedder.

In the region of the Scott's Peak and Edgar Dams, the Edgar Fault separates an Older Precambrian graphitic phyllite to the east from a Precambrian metasiltstone, argillite, quartz sandstone conglomerate to the west. Wedges of dolomite and limestone on its western side are truncated against the fault. During investigation of the Edgar Dam site about 1964 and prior to dam construction, geologists with the then Hydro-Electric Commission dug an $80 \mathrm{~m}$ long trench west from the scarp and excavated a number of co-linear pits. Their scope was to investigate possible water leakage along the scarp that cuts through the right abutment of Edgar Dam (Roberts et al., 1975). According to the authors «the Edgar Fault is a sinistral wrench fault trending approximately north-south with an original movement of approximately $12 \mathrm{~km}$. It passes within $76 \mathrm{~m}$ of the western end of Edgar Dam». They note that the «original fault movement dragged a narrow, possibly discontinuous, sliver of dolomite north from the main body a maximum distance of $1200 \mathrm{~m}$ ».

Roberts et al. (1975) also drilled an oblique hole to intersect the fault at about $100 \mathrm{~m}$ depth that showed it has a steeply dipping reverse component.

Starting in 1994 we made two field surveys of the scarp with assistance from Hydro Tasmania and Tasmanian Parks and Wildlife Service (McCue et al., 1996; Van Dissen et al., 1997). A post-reservoir filling aerial photograph looking north towards the small pond at the southern base of Edgar Dam is shown in fig. 3. An active fan flowing out of the ranges to the east is clearly dissected by the fault scarp. Carey had traced the scarp for nearly $12 \mathrm{~km}$ (7 miles) in the 1960s. On our second visit in 1997 we used a helicopter to track the surface rupture and found that it curved around to the southeast from its previously mapped southern end for another 13

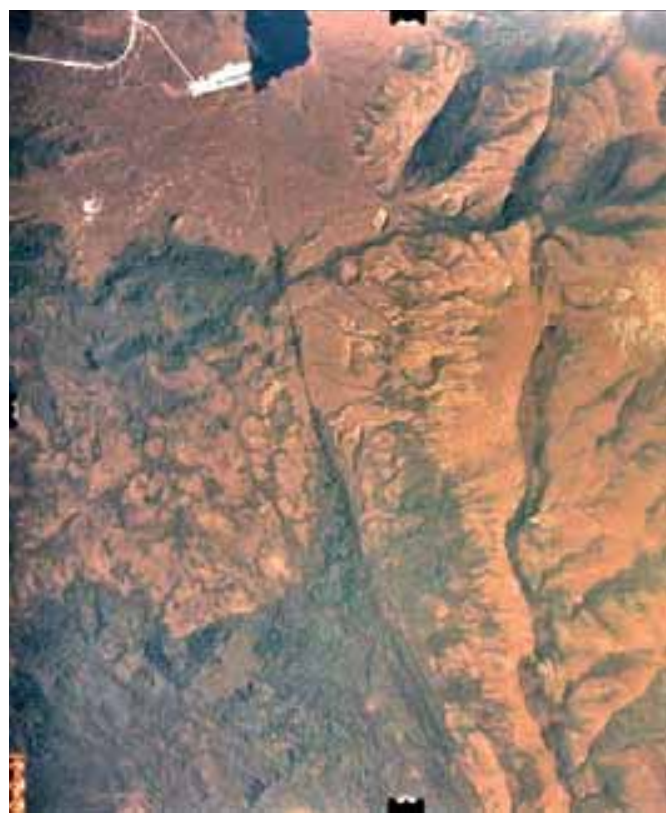

Fig. 3. Aerial photo of the Lake Edgar Fault, north up the page. A post-last-glaciation fan from the mountains to the east has planed and then been dissected by the last movement on the fault. Water ponded against the downstream face of Edgar Dam (off the top of the page) and the fault can be seen at the top of the photo. The prominent white east-west scar is a former airstrip, the trench and exploration pits are a few hundred metres parallel to and south of the airstrip (see fig. 5).

$\mathrm{km}$ (fig. 4). We subsequently confirmed this using 1960s-vintage black and white aerial photographs.

The water-filled trench was in good shape in 1994, 30 years after its completion, the walls were still vertical with only small collapse zones. With continuous water pumping we were able to reoccupy the trench near the centre of the surface fault and on the second field trip in 1997 briefly expose the overthrust glacial gravel layer at the former land surface. The inferred fault plane has a dip of about $60^{\circ}-70^{\circ}$ to the west at this nearsurface location.

McKavanagh (in Van Dissen et al., 1997) made three levelling traverses across the scarp as shown in fig. 5, north up the page. The central 


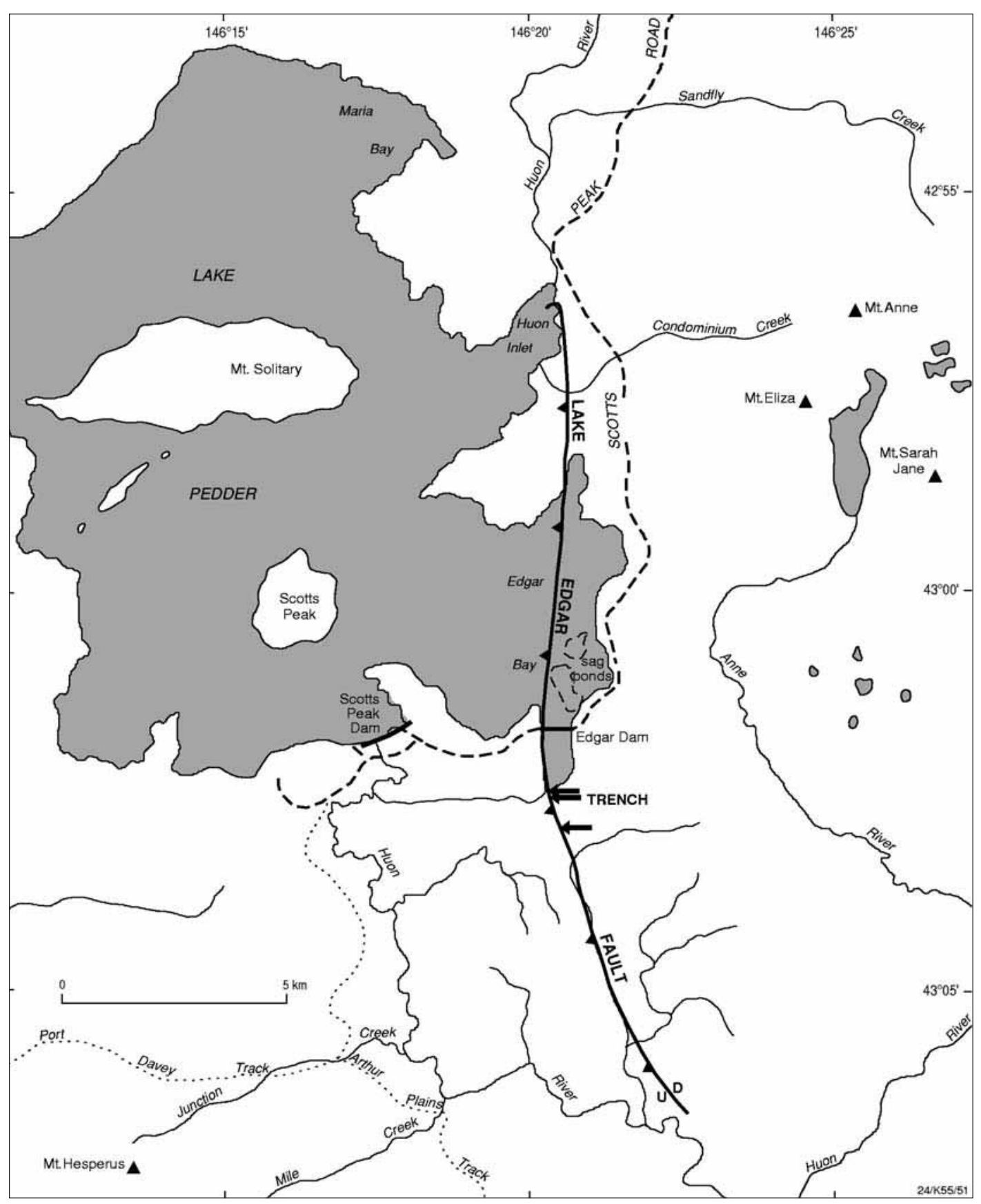

Fig. 4. Mapped surface expression of the Lake Edgar Fault, Tasmania, west side up. The three arrows show our levelling traverses. The relationship of the fault to two of the dams impounding Lake Pedder, Edgar Dam and Scotts Peak Dam is shown. 


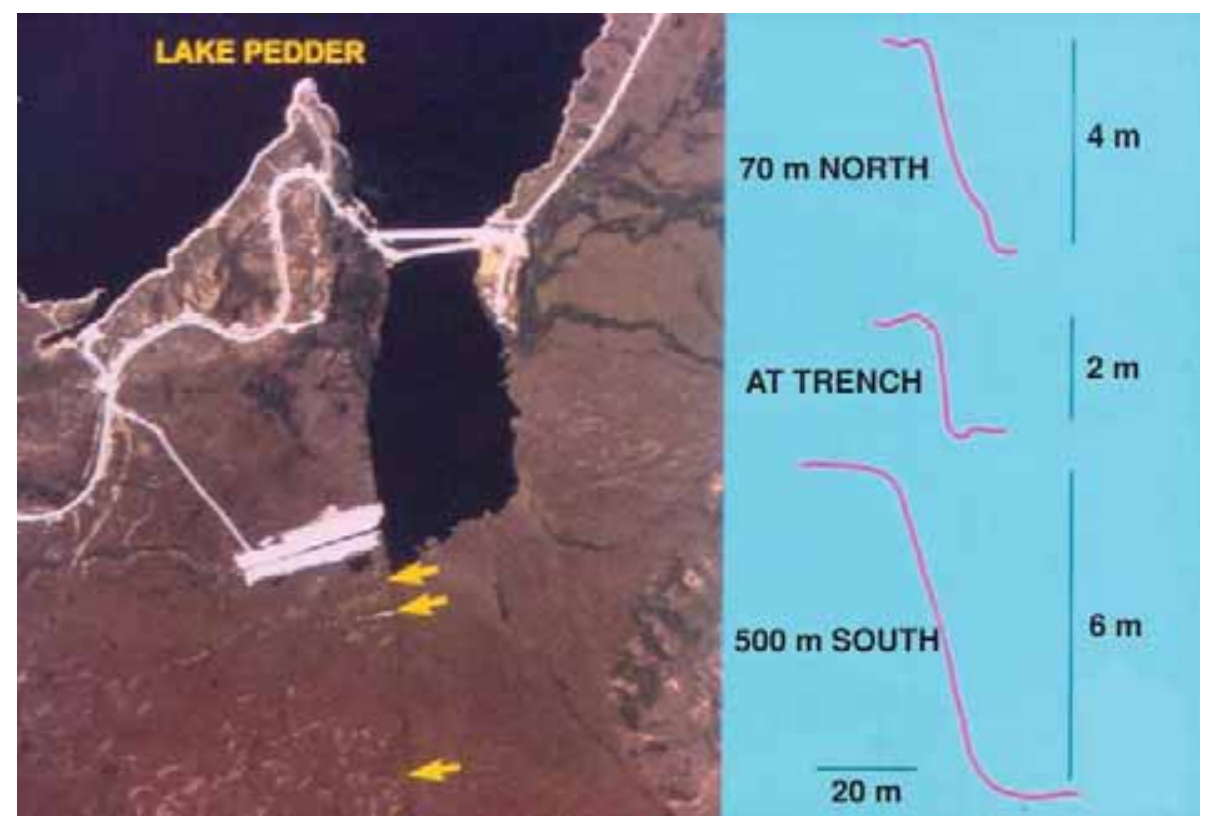

Fig. 5. Aerial photograph (north up the page) showing Edgar Dam and the location of surveyed cross sections (three arrows). The trench is the fine white line of exposed glacial gravels opposite the central arrow. Cross-section profiles are on the right.

traverse was alongside and parallel to the trench where the scarp is $2.5 \mathrm{~m}$ high. The trench and series of exploratory pits can just be seen in this figure on the western side of the scarp as a thin white line and line of white dots. Seventy metres north of the trench at the second traverse, the scarp is $4 \mathrm{~m}$ high. Our last traverse was $500 \mathrm{~m}$ south of the trench where the scarp approached its maximum height of $6 \mathrm{~m}$.

The unusual variability in the scarp height was a puzzle at first. But air photos such as that in fig. 3 show alluvial fans flowing west out of the ranges to the east and cutting across the central part of the scarp at its lowest point. Fan surges have planed off the scarp at least once and the fan has been cut in turn by subsequent fault ruptures. We interpret the $6 \mathrm{~m}$ high section to be a measure of the unaltered cumulative fault displacement. Our interpretation is shown in cartoon form in fig. 7 and discussed in more detail below.
Hale and Roberts (personal communication) identified another co-linear fault scarp, the Gell River Fault to the north of the Lake Edgar Fault scarp and about $30 \mathrm{~km}$ or a fault dimension away. Maximum crustal thickness in Tasmania is nearly $28 \mathrm{~km}$ with about $5 \mathrm{~km}$ of relief on the Moho (Richardson, 1989). Our aerial examination showed that the Gell River Fault scarp is more dissected and eroded than the Lake Edgar scarp and apparently older, but clear evidence that there was at least a third large Quaternary earthquake in Central Western Tasmania.

\subsection{Evidence for repeated Quaternary displacement}

Geomorphology - Deposits and landforms from four distinct glaciations have been identified in the Lake Edgar region (Colhoun and Fitz- 


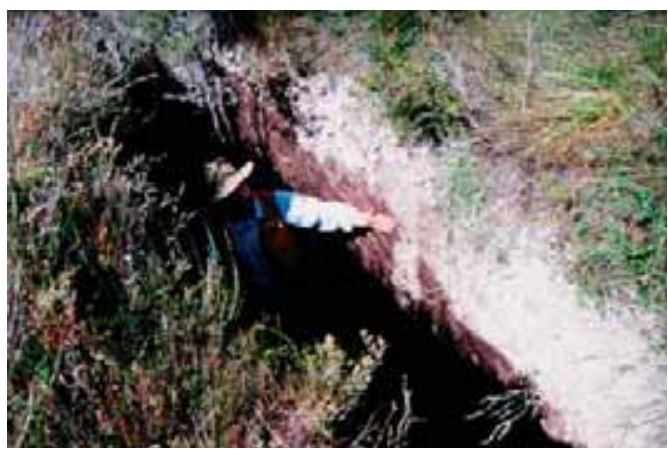

Fig. 6. The trench showing the white glacial fan gravels overlying basement. One of the authors (RvanD) is pointing out a gravel filled tension crack

simmons, 1990). The glaciations are thought to date from the Latest Pleistocene (youngest glacial maximum, 14000 to 25000 years BP, the glaciation finished by 10000 years BP), Middle Pleistocene (middle two glaciations), and Early Pleistocene or older (oldest glaciation, $c a .2$ Ma). The Lake Edgar Fault displaces till of the oldest glaciation, the scarp height across these highly weathered deposits is about $6 \mathrm{~m}$. The fault also cuts younger alluvial fans that correlate to the younger glaciations. Along the central portion of the fault and across the youngest fan the scarp is about $2.5 \mathrm{~m}$ high. Across the next oldest fan the scarp is about 5 $\mathrm{m}$ high. Older fans have higher scarps which indicates that the fault has generated at least two surface-faulting earthquakes within the Quaternary, possibly within the last 25000 years; the youngest being within the last $c a$. 10000 years.

Trench exposure - The $80 \mathrm{~m}$ long trench was excavated west from the fault scarp and near its centre where the youngest extensive fan that we consider Latest Pleistocene in age ( $\leq c a$. 10000 years) is draped over the scarp. Nearly three decades after the trench was dug, we pumped it dry and cleaned-down its walls and were rewarded with clear stratigraphic evidence of at least two surface-faulting earthquakes. A simplified trench log of the sunlit southern face of the trench is shown in fig. 8 .

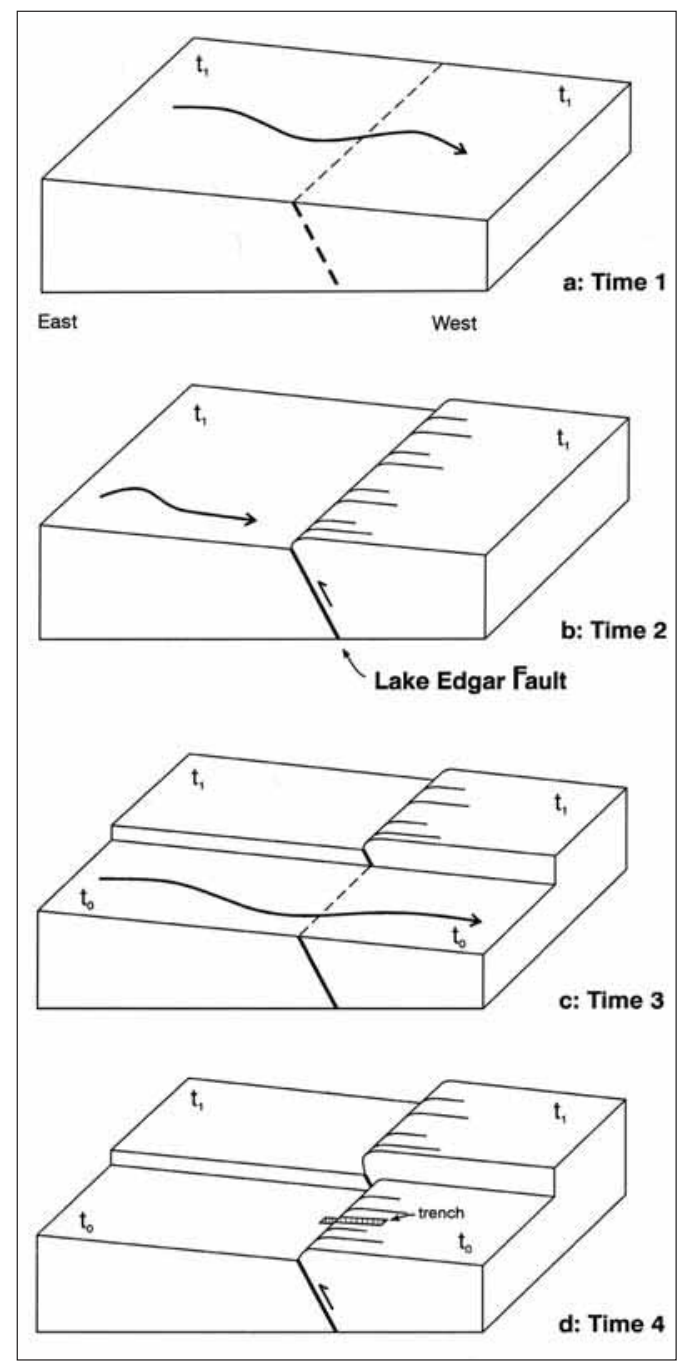

Fig. 7. Cartoon showing the sequence of scarp development; scarp formation, scarp planation by glacial fans and subsequent re-faulting. Time 4 is current time.

White fan gravels and underlying basement of sands and peats/lignites comprise the main units exposed in the trench (fig. 6). The oldest unit is a dark brown peat/lignite that contains diagenetic quartz laminae. These laminae, which probably formed parallel to the 


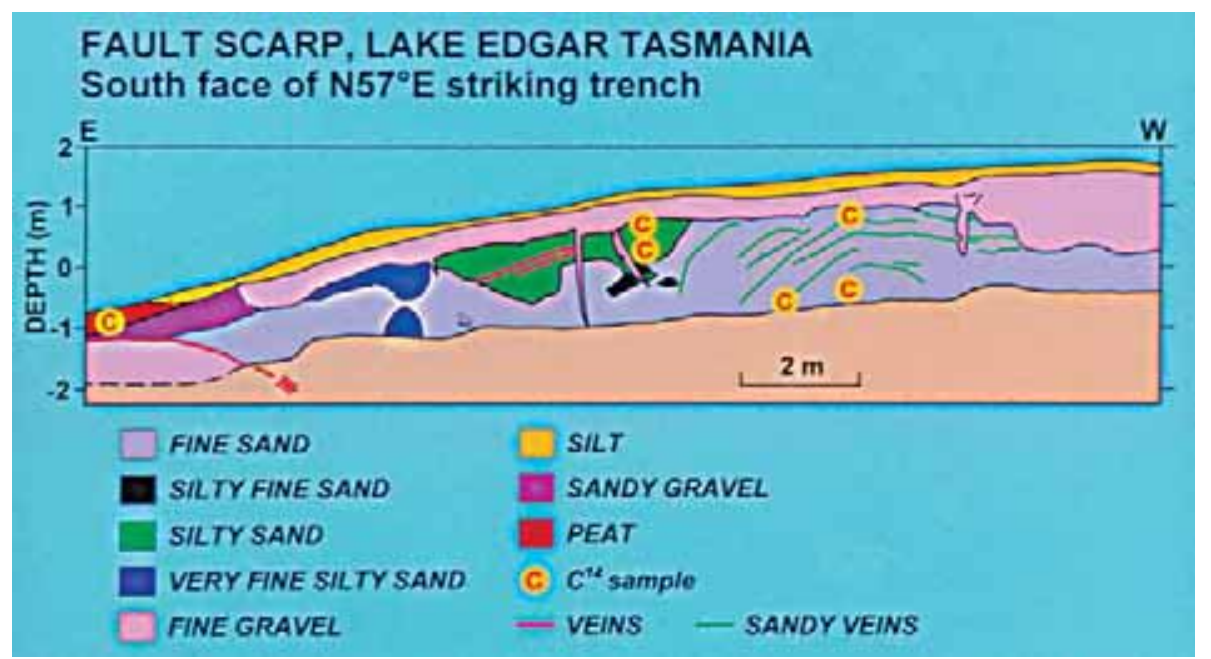

Fig. 8. Simplified log of the trench excavated through the Lake Edgar Fault. The fault trace is at the eastern end of the trench. The disturbed quartz laminae and truncated liquefaction sand lens are evidence of a previous faulting episode while the gravel filled tension cracks in the overthrust block are typical features of reverse faulting.

once horizontal bedding in the peat, are now deformed and locally attain dips of $45^{\circ}-80^{\circ}$ (fig. 8 ). Near the fault, fine white sand appears to have intruded into the peat/lignite. We interpret this sand unit as a sand-blow (Amick et al., 1990; Obermeier, 1994), a liquefaction feature resulting from strong earthquake ground shaking. The fan gravels comprise, in part, the youngest extensive fan, and are warped over the scarp that, at this locality, is about 2.5 $\mathrm{m}$ high (we take this to represent the amount of vertical displacement associated with the most recent surface-faulting earthquake). Two lines of evidence indicate older faulting:

i) The very fine, white, silty sand interpreted as a sand-blow is truncated by, and thus older than, the overlying gravel. The shaking that resulted in the emplacement of the sand-blow must be older than both the gravel and the surface-faulting that later deformed the gravel.

ii) Quartz laminae in the peat/lignite are more deformed than the overlying gravel, suggesting that the laminae were already deformed by at least one earthquake prior to the deposition, and subsequent deformation, of the younger gravel.
Several gravel filled tension cracks can be seen in the over-thrust block (fig. 8).

\subsection{Dating the last event}

Several charcoal samples were collected from pre and post-earthquake soil horizons to bracket the age of faulting (fig. 8), but the $\mathrm{C}^{14}$ dating results were disappointing. The fibrous dark brown peat on the ground surface of the footwall block at the fault was too modern and the samples from the body of the hanging wall block, a fine dark brown silty fine sand were too old (> 39600 years old).

As Carey said, the scarp must be recent for the ponds to have survived silting up in this high rainfall environment. The scarp itself is still very clear (figs. 4 and 5), in fact it is more prominent than the 1968 Meckering earthquake scarp in Western Australia which has been severely degraded, thanks in large part to farm management practices. The 1988 Tennant Creek earthquake scarp in the Northern Territory has also weathered extensively due to the sandy soil and infrequent but heavy downpours of rain. 
The last large earthquake on the lake Edgar Fault would have been felt throughout Tasmania and in Southern Victoria. The historic earthquake record of the last nearly 200 years contains no such reports so the earthquake predates the arrival and spread of European immigrants in Tasmania nearly 200 years ago. The event then was sometime between 200 years ago and the end of the last ice age $c a$. 10000 years ago. We consider that based on the subjective information of $\mathrm{C}^{14}$ dating of sediment deposition on the footwall block, on the non-silting up of Lake Edgar and on the sharp scarp morphology, the causative earthquake probably occurred nearer 200 than 10000 years ago.

\subsection{Earthquake magnitude estimate}

An approximate magnitude for causative earthquakes can be estimated, based on empirical relations between surface rupture parameters and earthquake magnitude. The mapped length of the Lake Edgar scarp is $29 \pm 4 \mathrm{~km}$, at least $25 \mathrm{~km}$ but no more than $33 \mathrm{~km}$ depending on its continuation into heavily wooded hilly country at its northern end. Vertical offset across the fault ranges from $2.5 \mathrm{~m}$ for the last faulting event to an average of $2 \mathrm{~m}$ (three events) or $3 \mathrm{~m}$ (two events).

McCue (1990) plotted magnitude $M$ against rupture length $L(\mathrm{~km})$ and maximum vertical displacement $u(\mathrm{~m})$ of the five Australian earthquakes ranging from $M 5.1$ to 6.8 that are known to have ruptured the surface. He obtained by least squares fit

$$
\begin{gathered}
M=4.11( \pm 0.18)+1.65( \pm 0.15) \log L \\
M=5.04( \pm 0.17)+0.75( \pm 0.10) u
\end{gathered}
$$

The first equation yields magnitudes of 6.4 to 6.6 for the range of the observed Lake Edgar Fault scarp length while the second yields magnitudes of 6.5 to 7.3 for the imputed uplift.

Wells and Coppersmith (1994) computed the regression of subsurface rupture length $L$ $(\mathrm{km})$ on magnitude $M$ for 167 earthquakes for all slip types. Magnitudes ranged from 4.7 to 8.2 .

$$
M=4.38+1.49 \log L
$$

This equation yields magnitudes of 6.5 to 6.6 for the range of the observed scarp length.

We consider that the Lake Edgar Fault is capable of generating earthquakes in the magnitude range $6 \frac{1}{2}-71 / 4$.

Calculations based on seismic moment considerations also yield magnitude estimates in the order of magnitude 7 .

\section{The Gell River Fault and possible relations with the Lake Edgar Fault}

About $30 \mathrm{~km}$ north of the Lake Edgar Fault lies another fault with apparent Late Pleistocene movement, the Gell River Fault which has a north-northeast trend and is $c a .10 \mathrm{~km}$ long (figs. 1 and 9). The active trace of the Gell River Fault appears to be more subdued than that of the Lake Edgar Fault; this could suggest that the most recent displacement of the Gell River Fault is older than that on the Lake Edgar Fault. Separating the two faults are two large bodies of ultramafic rock, including serpentinite and talc. The ultramafic rocks appear to be bounded by the northern extension of the Lake Edgar Fault (Burrett and Martin, 1989). The Gell River Fault is parallel to local geological structure, though based on existing mapping, it is not clear whether it is part of the structure that controls the location of the active trace of the Lake Edgar Fault.

We speculate that the recent activity on the Lake Edgar and Gell River Faults, and their geographic position relative to each other, is influenced by the occurrence of relatively weak ultramafic rocks along a major pre-existing fault. The more easily deformed talc and serpentinite between the two faults may, in essence, act to concentrate strain in the Lake Edgar and Gell River regions (Malcolm Somerville, personal communication). This strain may be released by creep in the weak ultramafic rocks. To the north and south, where the rocks are presumably 


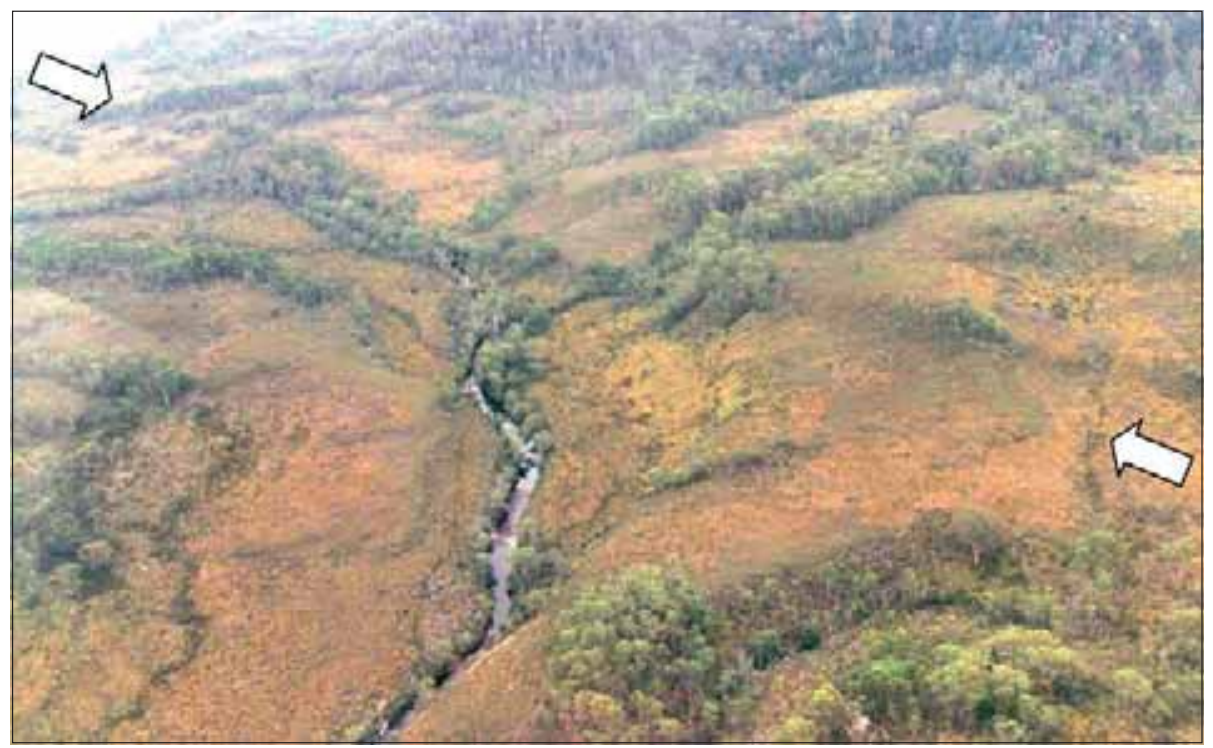

Fig. 9. Gell River Fault between arrows, oblique aerial photo looking west.

stronger, strain is released episodically as earthquake rupture along the Gell River and Lake Edgar Faults respectively.

\section{Conclusions}

The evidence of glacial fans offset by faulting and disproportionate displacement along the fault scarp led us to develop a model of fault growth, planation and subsequent faulting. This model demonstrates that the Lake Edgar Fault has generated at least two reverse surface-faulting earthquakes within the Quaternary, the most recent of these being younger than $\mathrm{ca} .10000$ years by which time the glaciers had melted. These earthquakes were probably in the order of $M 6^{1} / 2-7^{1} / 4$ in size, and produced, along the central portion of the fault, at least $2.5 \mathrm{~m}$ of vertical displacement.

There was at least one other Late Pleistocene earthquake in Central Western Tasmania on the Gell River Fault.

The spatial relationship between the Lake Edgar and Gell River faults, and temporal rela- tionships between surface-faulting earthquakes on these two faults, are probably influenced by one, or both, of the following:

i) the existence of a pre-existing fault which is oriented favourably, both with respect to strike and dip, for movement in the contemporary stress field, and

ii) the existence of large bodies of ultramafic rocks, including easily deformed talc and serpentinite, along the pre-existing fault which may concentrate strain in the Lake Edgar and Gell River areas.

The Lake Edgar Fault is the only identified Australian Fault with unequivocal evidence for repeated movement within the Late Pleistocene.

\section{Acknowledgements}

We are indebted to Dr. Malcolm Somerville (deceased), and thank Byron McKavanagh, and Dr. Albert Goede who participated in one of the field studies. This study benefited from discussions with numerous people; we would specifically like to acknowledge those with Glyn 
Roberts (formerly of the Hydro-Electric Corporation), Tom Laudon (University of Wisconsin), and Ruth and David Wilson (Hydro-Electric Corporation). We also wish to thank Hydro Tasmania, particularly Andrew Pattle, the dam safety officer, and the Tasmanian Parks and Wildlife Service. This study was sponsored by Hydro Tasmania as part of an ongoing program of assessing the seismic risk for their dams. Some financial support was also provided by the then Department of Industry, Technology and Commerce. We thank Kelvin Berryman as well as Des Darby, Kathleen Hodgkinson, and Mark Rattenbury for their suggestions to improve an earlier draft of this manuscript.

\section{REFERENCES}

Amick, D., G. Maurath and R. Gelinas (1990): Characteristics of seismically induced liquefaction sites and features located in the vicinity of the 1886 Charleston, South Carolina Earthquake, Seismol. Res. Lett., 61 117-130.

BurRetT, C.F. and E.L. MARTin (1989): Geology and mineral resources of Tasmania, Geol. Soc. Australia, Spec. Publ., 15, pp. 574.

Carey, S.W. and G. Newstead (1960): Tasmania University Seismic Net, Publication 84 (Geology Department, University of Tasmania).

Colmoun, E.A. and S.J. Fitzsimmons (1990): Late Cainozoic glaciation in Western Tasmania, Australia, Ouat. Sci. Rev., 9, 199-216.

Crone, A.J., M.N. Machette and J.R. Bowman (1997) Episodic nature of earthquake activity in stable continental regions revealed by paleoseismicity studies of
Australian and North American Quaternary faults, Aust. J. Earth Sci., 44, 203-214.

JOHNSTON, A.C. K.J. COPPERSMITH, L.R. KANTER and C.A. Cornell (1994): The earthquakes of Stable Continental Interiors, EPRI Report TR-102261-VI US.

McCuE, K.F. (1990): Australia's large earthquakes and recent fault scarps, J. Struct. Geol., 12, 761-766.

McCuE, K.F. (2001) Earthquake Epicentres in Australia 1841-2000 and Recent Fault Scarps, 1:10M map published by Geoscience Australia.

McCue, K.F., B. Boreham, R. Van Dissen, G. Gibson, V. JENSEN and B. MCKAVANAGH (1996): A paleoseismology case study: the Lake Edgar Fault scarp in Tasmania, in Proceedings of the 13th AGC, Canberra, 19-23 February 1996, GSA Abstracts 41, Geoscience for the Community.

OBERMEIER, S.F. (1994) Using liquefaction-induced features for paleoseismic analysis, U.S. Geol. Surv. OpenFile Rep. 94-663, chapter A, pp. 58.

Richardson, R.G. (1989) Crustal thickness, in Geology and Mineral Resources of Tasmania, edited by C.F. Burrett and E.L. Martin, Geol. Soc. Australia, Spec. Publ., 15, 465-467.

Roberts, G.T., B.A. Coleb and R.H.W. Barnett (1975): Engineering geology of Scotts Peak Dam and adjacent reservoir watertightness, Aust. Geomech. J., 39-45.

Turner, N.J. (1989): Precambrian, in Geology and Mineral Resources of Tasmania, edited by C.F. BuRRETT and E.L. Martin, Geol. Soc. Australia, Spec. Publ., 15, 5-46.

Van Dissen, R., K.F. McCue, G. Gibson, V. Jensen, M. Somerville, B. Boreham, B. McKavanagh and A. GoEDE (1997): The Lake Edgar Fault: evidence for repeated Quaternary displacement on an active fault in Southwest Tasmania, in Proceedings of the Seminar "Earthquakes in Australian Cities - Can we Ignore the Risks?», Australian Earthquake Engineering Society, Brisbane 2-3 October 1997.

Wells, D.L. and K.J. Coppersmith (1994): New empirical relationships among magnitude, rupture length, rupture width, rupture area, and surface displacement, Bull. Seismol. Soc. Am., 84, 974-1002. 
